\title{
Aryl hydrocarbon receptor activation mediates kidney disease and renal cell carcinoma
}

\author{
Hui Zhao ${ }^{1}$, Lin Chen ${ }^{1}$, Tian Yang ${ }^{1}$, Ya-Long Feng ${ }^{1}$, Nosratola D. Vaziri² ${ }^{2}$ Bao-Li Liu ${ }^{3}$, Qing-Quan Liu³ ${ }^{3}$ Yan Guo ${ }^{4}$ \\ and Ying-Yong Zhao ${ }^{1 *}$ (D)
}

\begin{abstract}
The aryl hydrocarbon receptor (AhR) is a well-known ligand-activated cytoplasmic transcription factor that contributes to cellular responses against environmental toxins and carcinogens. AhR is activated by a range of structurally diverse compounds from the environment, microbiome, natural products, and host metabolism, suggesting that AhR possesses a rather promiscuous ligand binding site. Increasing studies have indicated that AhR can be activated by a variety of endogenous ligands and induce the expression of a battery of genes. AhR regulates a variety of physiopathological events, including cell proliferation, differentiation, apoptosis, adhesion and migration. These new roles have expanded our understanding of the AhR signalling pathways and endogenous metabolites interacting with AhR under homeostatic and pathological conditions. Recent studies have demonstrated that AhR is linked to cardiovascular disease (CVD), chronic kidney disease (CKD) and renal cell carcinoma (RCC). In this review, we summarize gut microbiota-derived ligands inducing AhR activity in patients with CKD, CVD, diabetic nephropathy and RCC that may provide a new diagnostic and prognostic approach for complex renal damage. We further highlight polyphenols from natural products as AhR agonists or antagonists that regulate AhR activity. A better understanding of structurally diverse polyphenols and AhR biological activities would allow us to illuminate their molecular mechanism and discover potential therapeutic strategies targeting AhR activation.
\end{abstract}

Keywords: Aryl hydrocarbon receptor, Chronic kidney disease, Gut microbiota, Uremic toxins, Renal cell carcinoma, Natural products

\section{Background}

The induction of a battery of genes encoding xenobiotic metabolizing enzymes in response to chemical damage is an adaptive response in many organisms. The aryl hydrocarbon receptor (AhR) is a mediator of the toxic response of ubiquitous environmental pollutants such as halogenated aromatic hydrocarbons, polycyclic aromatic hydrocarbons and coplanar polychlorinated biphenyls [1-3], including 2,3,7,8-tetrachlorodibenzo-p-dioxin (TCDD), which has carcinogenic and teratogenic effects [4]. $\mathrm{AhR}$ is described as an environment-sensor period-aryl

\footnotetext{
*Correspondence: zyy@nwu.edu.cn; zhaoyybr@163.com

${ }^{1}$ Faculty of Life Science \& Medicine, Northwest University, No. 229 Taibai North Road, Xi'an 710069, Shaanxi, China

Full list of author information is available at the end of the article
}

hydrocarbon receptor nuclear translocator-single minded (Per-ARNT-Sim) protein that belongs to a member of the family of basic helix-loop-helix transcription factors [5].

\section{AhR signalling and its ligands AhR signalling}

$A h R$ is a ligand-mediated transcription factor implicated in the biological detoxification of ligands [6]. As shown in Fig. 1, under basal conditions, AhR is located in the cytoplasm in an inactive state as part of a complex formed with stabilizer proteins, including 2 molecules of heat shock protein 90 (HSP90), one molecule of cochaperone p23 (P23) and one molecule of X-associated protein 2 (XAP2) [1]. When a ligand binds to AhR, the AhR/ligand/Hsp90/XAP2 complex

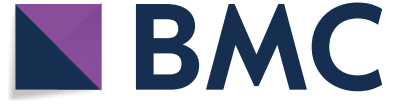

(c) The Author(s) 2019. This article is distributed under the terms of the Creative Commons Attribution 4.0 International License (http://creativecommons.org/licenses/by/4.0/), which permits unrestricted use, distribution, and reproduction in any medium, provided you give appropriate credit to the original author(s) and the source, provide a link to the Creative Commons license, and indicate if changes were made. The Creative Commons Public Domain Dedication waiver (http://creativecommons.org/ publicdomain/zero/1.0/) applies to the data made available in this article, unless otherwise stated. 


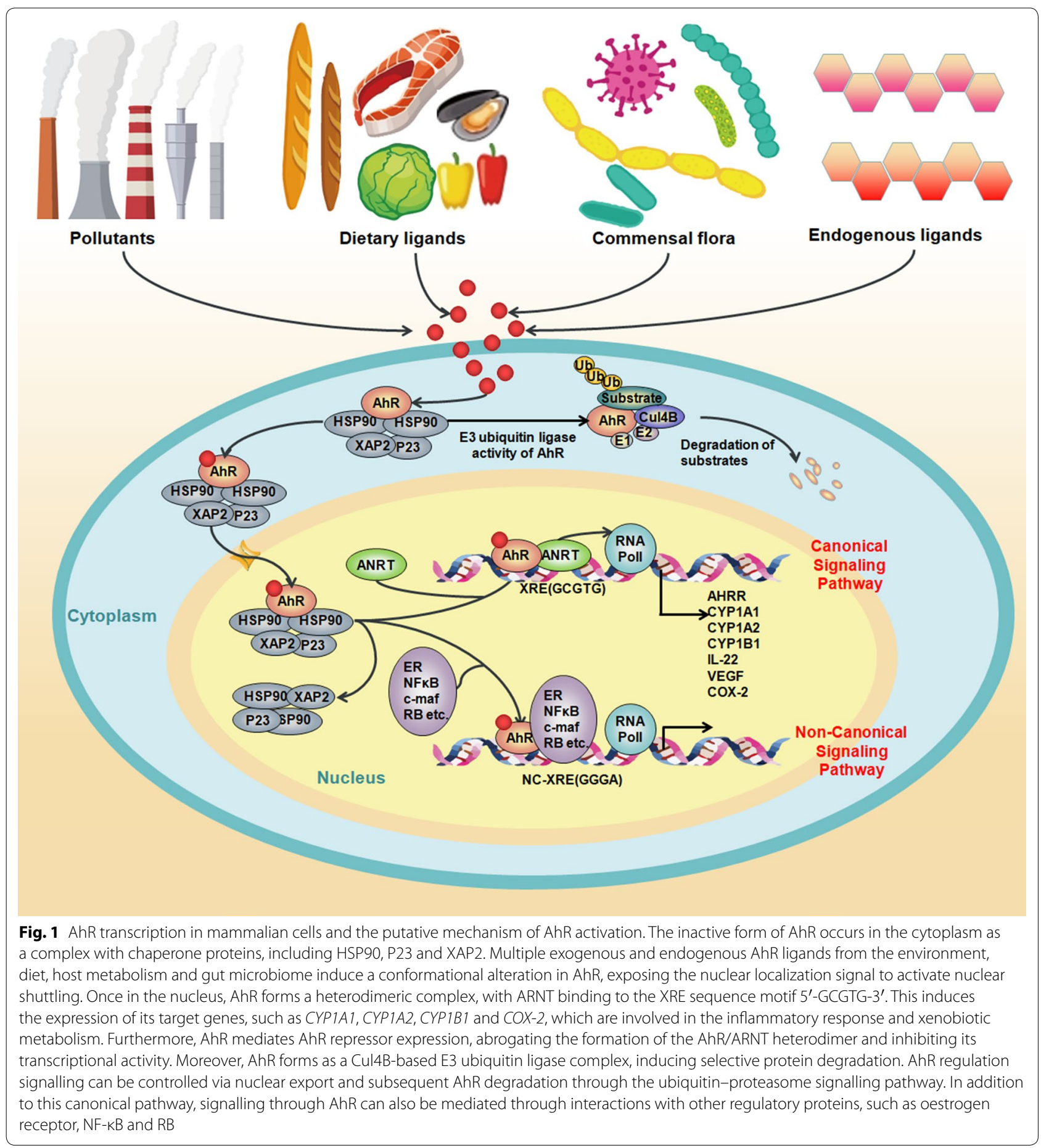

translocates into the nucleus and dimerizes with AhR nuclear translocator (ARNT). AhR is activated by a conformational alteration that exposes its nuclear localization sequence. After AhR is phosphorylated by protein kinase $C$, the $A h R$ complex is translocated into the nucleus [7]. In the nucleus, the complex releases the protein so that it can bind to the ARNT through its Per-ARNT-Sim domain, leading to the AhR-ARNT dimer. This AhR/ARNT heterodimer is recognized by a DNA-specific site, 5'-GCGTG-3', the DRE or XRE (dioxin- or xenobiotic-responsive element) sequence located within the promoters of target genes, and 
triggers their transcription, such as cytochrome P450, family 1 , member $1 \mathrm{~A}$ (CYP1A1); cytochrome P450, family 1, member 2A (CYP1A2); cytochrome P450, family 1 , sub family B (CYP1B1); AhR repressor $(A h R R)$; and cyclooxygenase-2 (COX-2). AhR induces the expression of xenobiotic enzymes, such as cytochrome P450 genes, needed for the detoxication of AhR toxic ligands [1].

AhR activation is primarily recognized to mediate the expression of phase I and phase II drug metabolism genes, including CYP1A1, CYP1A2, CYP1B1, UGT1A1/6 and sulfotransferase (SULT)1A1. Mounting studies have demonstrated that the AhR pathway is associated with diverse physiological functions and disease processes, such as the regulation of T-cell differentiation and embryonic/foetal development, the mediation of oxidative stress and inflammatory responses [8-13]. In fact, traditional AhR signalling cannot explain all the cellular functions attributed to AhR. In addition to the canonical gene regulation pathway, noncanonical AhR signalling has been described that includes crosstalk with other transcription factors, including nuclear factor kappa B (NF- $k B$ ), nuclear factor-erythroid-2-related factor 2 (Nrf2), programmed death ligand 1 and activator protein 1 (notably the RelA subunit), hypophosphorylated retinoblastoma protein, the corepressor oestrogen receptor and the progesterone receptor [14-16] (Figs. 1 and 2). Furthermore, cytosolic AhR can activate a myriad of other cytosolic proteins, including $\beta$-catenin, Smads, mitogen-activated protein kinase (MAPK) family p38, extracellular signal-regulated kinase (ERK) and Jun-NH2-terminal kinase (JNK) [17] (Fig. 2).

\section{Ligands of activated AhR signalling}

There is emerging evidence that chronic exposure to environmental chemicals via air and diet, particularly persistent organic compound pollutants such as TCDD or dioxin, causes side effects by ligand-activated induction of the AhR pathway [18-20] (Fig. 1). Moreover, there are also a myriad of endogenous AhR ligand candidates, such as eicosanoids (e.g., lipoxin A4, bilirubin, and lipopolysaccharides), and a myriad of naturally occurring flavonoids (e.g., resveratrol and quercetin). These endogenous metabolites have been identified as weak AhR ligands due to their low affinity for AhR (e.g., bilirubin and indirubin). However, bilirubin can activate AhR at a certain concentration in certain disease states, such as jaundice [21]. Human AhR preferentially binds to indirubin compared to mouse AhR [22].

\section{AhR activation through low-molecular-weight uremic toxins}

Metabonomics, which has been defined as "the quantitative measurement of the dynamic multiparametric metabolic response of living organisms to physiopathological stimulation or genetic modifications" [23, 24], is used as a comprehensive method to address changes in lowmolecular-weight metabolites $(\mathrm{MW}<1000 \mathrm{Da})$ following disease, toxic exposure or variation in genetic function [25-28]. Mounting studies by using burgeoning metabonomics have demonstrated that low-molecular-weight metabolites, such as cholesterols, amino acids, vitamins, lipids, carbohydrates, minerals and other compounds, play a critical role in health and diseases [29-33]. A number of novel or known metabolites have been used for disease diagnosis and prognosis, new drug discovery and toxicity evaluation [34-41].

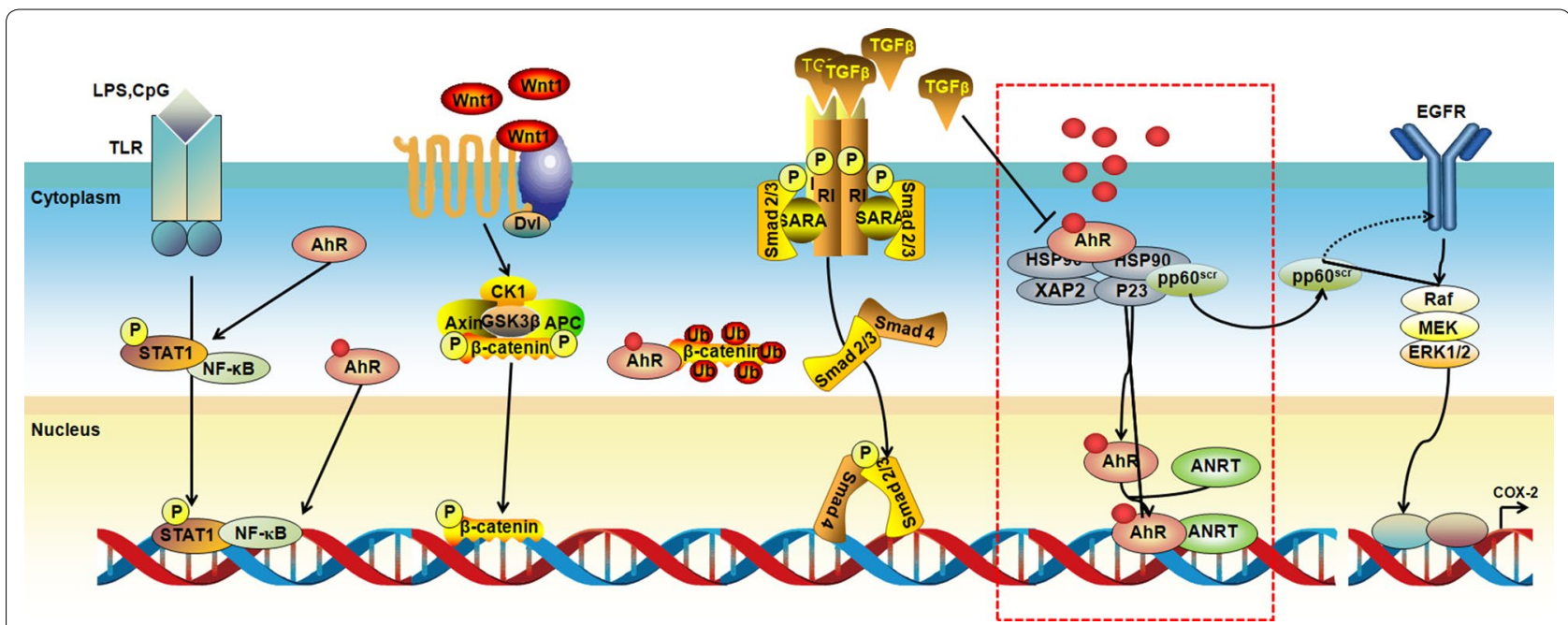

Fig. 2 AhR interacts with multiple other signalling pathways. AhR activates other cytosolic proteins, including $\beta$-catenin, Smads, ERK, p38MAPK and JNK 
Declining renal function leads to the retention of various metabolites [41-45] that are retained in the blood and various tissues instead of being excreted by the kidneys [46]. Thus, the retention of these metabolites contributes to a variety of diseases, especially chronic kidney disease (CKD) and cardiovascular disease (CVD) [47-50]. CKD leads to the retention of one of the most important metabolites, so-called uremic solutes. In 2003, the European Uremic Toxin Work Group classified 90 uremic compounds [51]. The number of compounds/ metabolites has since been extended [51]. Uremic toxins are classically categorized according to the physicochemical features affecting their clearance by dialysis: low water-soluble molecules ( $\mathrm{MW}<500 \mathrm{Da}$ ), larger middle molecules $(\mathrm{MW}>500 \mathrm{Da})$ and protein-bound molecules [52]. Protein-bound uremic solutes are poorly removed through conventional dialysis. Among the uremic toxins, tryptophan-derived uremic toxins are of particular interest because they are implicated in cardiovascular toxicity and have been demonstrated to be potent AhR ligands $[53,54]$. Tryptophan is an essential amino acid found in the diet. As shown in Fig. 3, 95\% tryptophan can be metabolized via the kynurenine pathway, which is mediated by the rate-limiting enzymes tryptophan 2,3-dioxygenase (TDO) and indoleamine 2,3-dioxygenase (IDO) [55]. TDO is highly expressed in the liver. IDO has two isoenzymes, IDO1 and IDO2. IDO1 expression has been demonstrated in most tissues [55]. The activity of IDO leading from tryptophan to kynurenine is reflected by the tryptophan/kynurenine ratio [56]. Serum tryptophan is decreased in CKD patients, whereas metabolites from the kynurenine pathway, including kynurenine, kynurenic acid, 3-hydroxykynurenine, anthranilic acid and quinolinic acid, are increased. Two other tryptophan metabolic pathways are the serotonin pathway, which produces melatonin, and the indolic metabolic pathway, which produces indolic compounds, including indoxyl sulfate (IS), indole-3-acetic acid (IAA) and indoxyl- $\beta$-D glucuronide (IDG) (Fig. 3). In the indolic pathway, tryptophan is converted to indole through gut microbiota and absorbed into blood circulation [57] (Fig. 3). For instance, tryptophanase produced from Escherichia coli metabolizes dietary tryptophan to indole and its derivatives [58]. In the liver, bacterial-derived indole is further metabolized to IS via human SULT1A1 [59]. Moreover, indole is oxidized to IS by microsomal CYP2E1 [60]. IAA is directly produced in the gut by tryptophan metabolism or endogenously in tissue through tryptamine [60]. For example, tryptophan mono-oxygenase produced by Arthrobacter pascens and tryptophan decarboxylase produced by Clostridium sporogenes convert tryptophan into the AhR ligands IAA and tryptamine, respectively [61-63]. In the healthy state, the human gut microbiota carries out several activities to the body. Gut microbiota live in a commensal relationship with their host, protecting against pathogens, modulating the immune system, and regulating endogenous lipid and carbohydrate metabolism, thus maintaining the nutritional balance [64]. An increasing number of recent studies have demonstrated that alterations in gut microbiota are linked with a myriad of diseases, such as cancer, obesity, diabetes, cardiovascular disease, inflammatory bowel disease, and kidney disease [65]. It is increasingly recognized that gut microbiota metabolism contributes to the generation of enormous uremic toxins [66-69].

Although uremic toxins contribute to various diseases associated with a variety of action mechanisms, some metabolites, such as aromatic hydrocarbon metabolites and indole derivatives, have been demonstrated as endogenous AhR ligands and thus could evoke AhR activation [70]. Further study indicated that $A h R$ seems to sense microbial insults and bacterial virulence factors, constituting a new AhR ligand [71]. Increasing evidence has also demonstrated that tryptophan metabolismderived uremic toxins such as IS, IAA and IDG are recognized as the most important endogenous AhR ligands and thus can trigger AhR activation [72, 73] (Fig. 3). IS, IAA and IDG can activate AhR signalling via direct binding to the AhR/Hsp90/XAP2 complex. Both IS and IAA upregulate eight genes of AhR, including $C Y P 1 A 1$ and CYP1B1 [74].

IS has been reported as one of the most important uremic toxins. A panel of indole derivatives including tryptophan, indole, IS, IAA, and indole 3-methanol as AhR ligands has been examined [59]. IS has been demonstrated as a potent endogenous ligand that selectively activates human AhR at nanomolar level in primary human hepatocytes, mediating the transcription of multiple AhR genes, including CYP1A1, CYP1A2, CYP1B1, UGT1A1, UGT1A6, interleukin 6 and serum amyloid A1. Furthermore, IS exerts a 500fold greater potency in the transcriptional activation of human AhR compared to mouse AhR [59]. Structurefunction findings have indicated that the sulfate group is an important factor for effective AhR activation. Ligand competition binding analyses have indicated that IS is a direct AhR ligand [59]. Previous studies have shown that IS suppresses endothelial proliferation, inhibits wound repair and triggers oxidative stress [72]. IS has been implicated in cardiovascular mortality and classical risk factors in CKD patients. Basal AhR level regulate podocyte function under normal circumstances, and upregulating AhR activation in podocytes by IS contributes to glomerular injury [75]. Activated AhR by IS triggers a proinflammatory phenotype, podocyte damage and glomerular injury both in vivo 


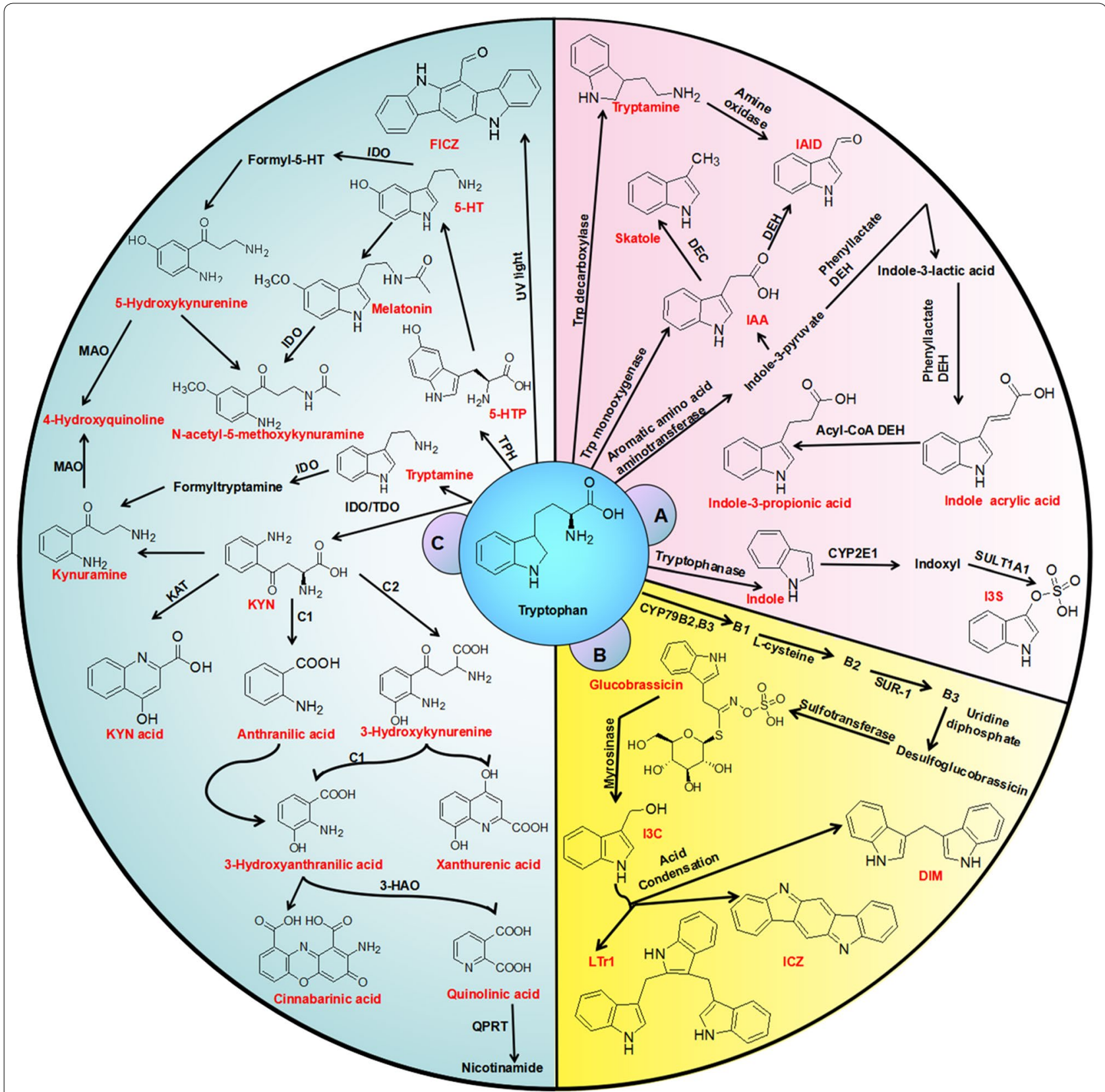

Fig. 3 Biosynthesis of AhR ligands from tryptophan metabolism. Tryptophan is metabolized into various AhR ligands. a In the gastrointestinal tract, various bacterial species in the microbiota can metabolize tryptophan to products with AhR agonistic effects. $\mathbf{b}$ Cruciferous vegetables produce the tryptophan metabolite glucosinolate via a hydrolysis reaction, yielding the AhR protoagonist I3C. In the stomach, I3C is metabolized by an acid-condensation reaction to AhR ligands 6-formylindolo(3,2-b)carbazole (FICZ), DIM and LTr1. c Host metabolites such as IS and IAA, with AhR agonistic effect, are primarily derived from tryptophan metabolism through the kynurenine pathway, with other ligands generated by ultraviolet exposure and oxidative reactions. B1: indole-3-acetaldehyde; B2: S-(indolylmethylthiohydroximoyl) L-cysteine; B3: indolylmethyl thiohydroximate; TPH: tryptophan hydroxylase

and in vitro [75]. Another study reported that increased IS affected iron metabolism in adenine-induced CKD mice by participating in hepcidin regulation via AhR and oxidative stress pathways [76]. Moreover, the activation of $A h R$ mediated the IS-mediated upregulated expression of monocyte chemoattractant protein-1 (MCP-1) in human umbilical vein endothelial cells (HUVECs) [77]. IAA is another important uremic toxin. IAA activates the AhR/p38MAPK/NF-kB signalling pathway, which induces COX-2 expression, and 
IAA increases the production of reactive oxygen species both in vivo and in vitro [78]. Therefore, serum IS or IAA might be an independent indicator of cardiovascular events and mortality in CKD patients.

Other toxins from tryptophan metabolism reported as AhR ligands are from the kynurenine pathway. Kynurenic acid can induce the AhR signalling pathway in patients with CKD [79]. Moreover, 5/6 Nx rats exhibit high levels of serum kynurenine and 3-hydroxykynurenine and significantly upregulated AhR and CYP1A1 mRNA expression in bone tissue compared to control rats [80]. Notably, the serum kynurenine level, the serum kynurenine/tryptophan ratio, and AhR and CYP1A1 mRNA expression are lower in 3-month-old 5/6 Nx rats compared to 1 -month-old $5 / 6 \mathrm{Nx}$ rats [80].

\section{AhR activation mediates renal damage The AhR pathway is activated in CKD}

Patients with CKD are exposed to a high level of uremic toxins, causing an increased risk of cardiovascular disease. A number of uremic toxins, such as IS, IAA and IDG, are agonists of AhR. The latest study demonstrated that AhR was activated in patients with CKD stage 3 to $5 \mathrm{D}$ [81]. AhR-activating potential (AhR-AP) strongly correlates with eGFR and IS concentration. The expression of blood AHR target genes, including CYP1A1 and AhRR, is upregulated in CKD patients compared to healthy controls [81]. Further study demonstrated that 5/6 nephrectomized $(5 / 6 \mathrm{Nx})$ mice exhibited an increase in serum AhR-AP and an induction of CYP1A1 mRNA expression in the heart and aorta that were absent in $\mathrm{AhR}^{-1-} \mathrm{CKD}$ mice [81]. Increased serum AhR-AP level and upregulated CYP1A1 mRNA level in the aortas and hearts from WT mice have been observed after serial IS injection, but not in $\mathrm{AhR}^{-1-}$ mice [81]. Taken together, these results suggest that the $A h R$ signalling pathway is activated in both mice and patients with CKD.

Another study demonstrated that indolic uremic solutes upregulated tissue factor expression by an AhRdependent pathway in patients with CKD (stages 3-5D) compared to healthy controls, evoking a 'dioxin-like' effect. Elevated tissue factors were positively correlated with serum IS and IAA concentrations in patients with CKD (stages 3-5D) [74]. In HUVECs, IS and IAA treatment further upregulated the expression of eight AhR genes: CYP1A1, CYP1B1, CYP1A2, transforming growth factor $\beta-3$, prostaglandin $G / H$ synthase and cyclooxygenase, CDD-inducible poly(ADP-ribose) polymerase, chemokine (C-C motif) receptor 7 and $A h R R$, the repressor of AhR [74]. The involvement of AhR activation in tissue factor production has been clarified by siRNA inhibition and with the AhR inhibitor geldanamycin [74]. These findings were amplified in peripheral blood mononuclear cells. The expression and activity of tissue factors were also augmented by TCDD. In addition, the IS level is significantly correlated with both $\mathrm{AhR}$ and tissue factor activities in patients with end-stage renal disease (ESRD) [82]. IS activates the AhR pathway in primary human aortic vascular smooth muscle cells, and AhR interacts directly with and stabilizes tissue factor. The AhR antagonist inhibits tissue factor, enhances tissue factor ubiquitination and degradation, and inhibits thrombosis and endovascular injury [82]. Moreover, monocytes respond to IS through AhR signalling and consequently upregulate tumour necrosis factor alpha expression in ESRD patients [83]. Taken together, these findings indicate that the activation of AhR is a key mechanism associated with deleterious cardiovascular disease in CKD.

However, the knockout of AhR leads to altered renal and hepatic phenotypes in both mice and rats [84]. AhRknockout mice show changes in hepatic function and liver patent ductus venosus. AhR-knockout rats exhibit alterations in the urinary tract, including bilateral renal dilation (hydronephrosis), secondary tubular and uroepithelial degenerative alterations and bilateral ureter dilation (hydroureter) [84]. Another study indicated that aromatic hydrocarbons can compensate for renal cell function by intervening with mitochondrial function and glutathione homeostasis and are involved in both mesenchymal and epithelial populations in nephrotoxicity to this heterogeneous class of chemicals [85]. In addition, AhR stimulation can represent a novel renoprotective effect likely involving the mobilization and recruitment of Tregs and stem cells to the injured kidney [86].

The serum IS level is between 7 and $343 \mu \mathrm{M}$ (mean value: $120-140 \mu \mathrm{M}$ ) in chronic haemodialysis patients [87]. IS circulates in albumin-bound and free forms. In haemodialysis patients, approximately $90 \%$ of IS is bound to serum proteins, indicating that the free serum IS level is $12 \mu \mathrm{M}$, an effective level that leads largely to the induction of AhR activity in cultured cells [88]. The IS level is highest in the kidney and lower in the lung, liver and heart in nephrectomized rats [89]. Rats with chronic renal failure showed sixfold higher IS level in kidney tissues and $71 \mu \mathrm{M}$ IS in kidney homogenate. If these findings reflect the kidney tissue IS level in patients with ESRD, it would be expected that AhR could be fully activated and that AhR activation would further enhance the expression of AhR target genes, such as CYP1A1, $C Y P 1 A 2, C Y P 1 B 1$ and $C O X-2$. Another study indicated that CYP1A2 protein expression in the kidney and liver was greatly upregulated in rats with chronic renal failure [90]. In addition, TCDD can mediate hydronephrosis in mice [91]. TCDD toxicity is solely induced by AhR and thus could provide the clues for the inhibitory effects of elevated AhR activity mediated by high IS level. 
Free IS, not albumin-bound IS, can activate AhR. One study investigated the effect of albumin-bound and free IS on AhR activation using IS level observed in different stages of patients with CKD. An AhR-driven reporter assay showed that both IS forms mediated dose-dependent AhR transcription in vascular smooth muscle cells [82]. IS level equivalent to those found in early stages of patients with CKD also increased AhR transcription, which was dose-dependently inhibited by the AhR antagonist CB7993113. Similarly, IS upregulated the expression of endogenous AhR target genes CYP1A1, CYP1A2 and $A h R R$, all of which were abrogated by the AhR antagonist [82]. However, few studies have examined the effect of IS on AhR activity in renal proximal tubular cells. Taken together, these results show that upregulated AhR activity in the kidney may be associated with the high IS level in renal disease.

\section{The AhR pathway is activated in diabetic nephropathy}

Diabetic nephropathy has become a large global health problem. It has been reported that serum AhR transactivating activity is higher in type 2 diabetic patients with diabetic nephropathy with microalbuminuria, macroalbuminuria and ESRD than in subjects with normoalbuminuria [92]. Serum AhR ligands are correlated with the estimated glomerular filtration rate (eGFR), the serum creatinine level, systolic blood pressure, glycated haemoglobin and diabetic duration. High AhR transactivating activity is an independent risk factor in diabetic nephropathy [92]. A study on streptozotocin-induced diabetic mice showed that AhR deficiency reduced the induction of COX-2/prostaglandin $\mathrm{E}_{2}, \mathrm{NADPH}$ oxidase activity, oxidative stress, lipid peroxidation and $N-\varepsilon$ carboxymethyllysine [93]. $N$ - $\varepsilon$-carboxymethyllysine significantly enhanced AhR/COX-2 DNA-binding activity, protein-DNA reciprocity, gene regulation, and ECM accumulation in renal proximal tubular cells and mesangial cells, which might be reversed by siRNA-AhR transfection [93]. In addition, human kidney dysfunction occurring as a result of diabetic nephropathy has been indicated to lead to high serum IS level [59].

\section{AhR is associated with the RAS}

The renin-angiotensin system (RAS) plays a key role in the progression of CKD. Several studies have indicated that AhR is associated with the RAS. For example, IS reduces the expression of the Mas receptor in the aortas of normotensive and hypertensive rats [94]. Another study demonstrated that IS downregulated the expression of the Mas receptor via AhR/NF- $\mathrm{kB}$ and mediated cell proliferation and tissue factor expression in human aortic smooth muscle cells. Ang-(1-7) suppressed ISmediated tissue factor expression and cell proliferation by inhibiting phosphorylated ERK1/2 and NF-kB [94]. In addition, the expression of the Mas receptor is downregulated in the kidneys of rats with CKD [95]. IS induces the downregulation of the expression of the Mas receptor through the OAT3/AhR/STAT3 signalling pathway in proximal tubular cells [95]. The IS-mediated downregulation of the Mas receptor is involved in the upregulation of transforming growth factor beta 1 in proximal tubular cells. Another study indicated that IS induced the aortic expression of prorenin receptor and renin/prorenin via organic anion transporter 3-induced uptake, reactive oxygen species production and AhR and NF- $\mathrm{kB}$ p65 activation in vascular smooth muscle cells [96]. The ISinduced activation of the prorenin receptor promotes tissue factor expression and cell proliferation in vascular smooth muscle cells [96].

\section{The AhR pathway is activated in urinary system-associated cancers}

The AhR pathway is involved in carcinogenesis [97]. It has been demonstrated that AhR is mainly expressed in the nuclei of advanced clear cell renal cell carcinoma (RCC) and tumour-infiltrating lymphocytes, and its expression correlates with the stage of the pathological tumour and the histological grade [98]. Matrix metalloproteinases (MMP) belong to a family of zinc-dependent endopeptidases and are considered as therapeutic targets for renal diseases [99]. AhR activation upregulates the mRNA expression of its target genes $C Y P 1 A 1$ and $C Y P 1 B 1$ and promotes invasion by upregulating the mRNA expression of $M M P-1, M M P-2$ and $M M P-9$ and downregulating the mRNA expression of E-cadherin in human RCC cell lines, including 786-O and ACHN [98]. Furthermore, a siRNA for AhR downregulated CYPs and inhibited cancer cell invasion accompanied by the downregulation of MMP in 786-O cells [98]. These findings indicate that AhR regulates cell RCC invasion involved in tumour immunity. The same study group showed that nuclear AhR expression was also significantly related to pathological $\mathrm{T}$ stage, histological grade, invasion and lymph node involvement in patients with upper urinary tract urothelial carcinoma [100]. AhR expression is considered an independent predictor of disease-specific survival. T24 UC cells induced by TCDD showed the upregulated mRNA expression of AhR, CYP1A1 and CYP1B1 accompanied by the upregulated mRNA expression of $M M P-1$ and $M M P-9$ and enhanced T24 cell invasion [100]. Furthermore, T24 cells transfected with a siRNA for AhR showed the downregulated mRNA expression of $A h R, C Y P 1 A 1, C Y P 1 B 1$, $M M P-1, M M P-2$ and $M M P-9$ and indicated decreased invasion ability [100]. Taken together, these findings indicate that AhR plays an important role in the invasiveness of cancer cells and can serve as a prognostic biomarker 
and potential therapeutic target for patients with urinary system-associated cancers.

\section{Natural products such as AhR agonists or antagonists in kidney disease and renal cell carcinoma}

Organic anion transporting polypeptides and organic anion transporters play a key role in renal uremic toxin elimination. Solute carrier organic anion transporter family member $4 \mathrm{C} 1$ (SLCO4C1) is the only organic anion transporting polypeptide expressed at the basolateral side of human renal proximal tubular cells, and it modulates uremic toxin excretion. Human SLCO4C1 overexpression in rat kidneys promotes renal uremic toxin excretion and lowers cardiomegaly, hypertension and renal inflammation in renal failure [101]. Statin induces SLCO4C1 expression via $\mathrm{AhR}$ by binding to the XRE at its promoter region [101]. Statin administration promotes the elimination of uremic toxins and mitigates organ damage in a rat renal failure model. MicroRNAs play an important role in the cellular defence mechanism. It has been reported that miR-125b is transcriptionally activated by Nrf2 and could be an inhibitor of the AhR repressor in cisplatininduced mice, which contributes to protecting the kidney from acute kidney injury [102].

Natural products in the clinic have been regarded as an alternative therapy for the prevention and treatment of a myriad of diseases worldwide [103-107]. Natural products also continue to provide a protean and unique source of new bioactive lead candidates for drug discovery [108-115]. Numerous studies have demonstrated a variety of natural product-derived compounds that can directly activate or inhibit AhR [116-119]. As early as the 1970s, several studies reported that the ligands of AhR from vegetable extracts or vegetable-derived materials mediate CYP1A1 activity [120,121]. As shown in Fig. 3, members of the cruciferous family, such as broccoli, brussels sprouts, white cabbage and cauliflower, have rich sources of glucobrassicin or glucosinolate conjugates that produce indole-3-carbinol (I3C) and indole-3-acetonitrile (I3AC) by using enzymatic cleavage during mastication [122, 123]. I3C and I3AC can bind to and activate AhR. Indolo[3,2,-b]carbazole (ICZ) and 3,3'-diindolylmethane (DIM) are two major acidic condensation products of I3C. ICZ has a higher affinity for the AhR ligand compared to other natural products [124]. 3,3'-Diindolylmethane is an established AhR agonist [124]. Glucosinolate conjugates can activate AhR in mice and humans [121, 125]. After consumption, glucosinolates undergo hydrolysis, transferring I3C, ICZ, DIM and ([2-(indol-3ylmethyl)-indol-3-yl] indol-3-ylmethane (LTr1), which serve as AhR agonists [121]. These compounds are involved in gut AhR expression needed for the maintenance of innate lymphoid cells and intraepithelial lymphocytes. These findings demonstrate an important link between dietary factors, AhR and intestinal immunity. Subsequently, studies demonstrated that a number of compounds from natural products, such as I3C, curcumin, quercetin, resveratrol, 7,8-dihydrorutacarpine, dibenzoylmethanes and carotinoids (canthaxanthin, astaxanthin and $\beta$-apo- $8^{\prime}$-carotenal), could competitively bind to AhR and/or mediate the expression of AhRdependent genes $[116,117,123,126]$.

Polyphenols are widespread compounds throughout the plant kingdom [127]. They are characterized by using a classic phenol ring chemical structure. According to the phenol ring amounts in compounds and the approach they use, polyphenols are divided into 5 categories: flavonoids, phenolic acids, stilbenes, lignans and tannins [128]. Flavonoids and phenolic acids are the most abundant polyphenols in the daily diet and can be further divided into several categories based on the oxidation degree of the oxygen heterocycle, including flavonols, flavanols, flavanones, flavones, isoflavones, proanthocyanidins and anthocyanins [128]. Flavonoids from natural products constitute the largest category of AhR ligands $[117,129,130]$. Flavonoids, such as kaempferol, (-)-epigallocatechin gallate, luteolin, myricetin, epigallocatechin, morin, galangin, eriodictyol, tangeritin, apigenin and naringenin, are mostly AhR antagonists, but some of them, including chrysin, baicalein, quercetin, diosmin, icaritin, tangeritin, and tamarixetin, are $A h R$ agonists $[116,117,126]$. In addition to interplaying with $\mathrm{AhR}$, many flavonoids are also substrates for CYP1A1. These flavonoids are widely distributed in medicinal plants, fruits, vegetables and teas, and flavonoid concentrations in human blood are in the low micromolar range, levels sufficient to inhibit/activate AhR [116]. Thus, it is not surprising that the extracts of many natural products exhibit AhR agonist and/or antagonist activity. Therefore, natural products commonly include AhR ligands or natural products that can be transformed into AhR ligands, and as such, flavonoids are the largest class of natural AhR ligands that are available for humans and animals. Mounting evidence has demonstrated that polyphenols, especially flavonoids, as modulators of AhR, are widely used for the regulation of the intestinal immune system and tumour treatment [116-118, 131, 132], but only several studies have reported that natural products regulate AhR in kidney damage.

Aristolochic acids, such as aristolochic acid I (AAI) and aristolochic acid II, with the structure of nitrophenanthrene carboxylic acids, are the main active component of Aristolochia species [133]. Aristolochic acids were known to possess anti-inflammatory properties until the first case of nephropathy was found in Belgium, which is now regarded as aristolochic acid nephropathy (AAN) [134]. 
AA exposure was recently implicated in Balkan endemic nephropathy and associated with urothelial cancer $[135,136]$. The mechanism revealed that AAI-mediated nephrotoxicity is associated with deficient liver-specific NADPH-cytochrome P450 reductase, and the induction of CYP1A significantly lowers AAI-induced kidney toxicity [134]. Baicalin significantly alleviates AAI-mediated kidney toxicity via AhR-dependent CYP1A1 and CYP1A2 induction in the liver [137]. Tanshinone I promotes AAI metabolism and prevents AAI-mediated kidney injury by the induction of hepatic $C Y P 1 A 1$ and $C Y P 1 A 2$ in vivo [138].

\section{Concluding remarks}

Initially, AhR was discovered as a chemical-sensing signalling molecule that mediated the toxic responses from environmental pollutants. In recent years, increasing studies on AhR ligands have testified an unparalleled expansion from exogenous toxic responses to many biology- and medicine-related fields, such as cancer, immunity regulation, cardiovascular disease and kidney disease. AhR signalling exhibits a variety of biological functions that have expanded its classical transcriptional function into the regulation of the cytosolic signalling pathway and possesses novel endogenous ligands that can bind to and activate AhR-dependent gene expression. Although the recently reported AhR ligands have expanded greatly, many related studies of AhR are still rigorously challenging, and great effort should be made in the future.

First, the structural identification of AhR ligands could provide insight into novel exogenous and endogenous ligands of AhR. Although fractionation approaches of biological samples could not identify many endogenous ligands in the past, the latest development of highthroughput, rapid and sensitive metabolomic approaches provides avenues for the identification, isolation, and characteristics of new AhR ligands from trace amounts of complex matrices and biological samples. Metabolomics and lipidomics have been successfully utilized to discover and identify a variety of novel endogenous AhR ligands, especially aromatic hydrocarbon-containing metabolites (uremic toxins), in both animal models and patients with CKD [50, 139-143]. Overall, characterization of the spectrum of endogenous AhR ligands will provide novel molecular and biochemical mechanisms by which ligands can induce AhR activation.

Second, natural products have been extensively used for the prevention and intervention of a myriad of diseases worldwide. Investigators revealed an intriguing trend in drug development beginning in the 21st century: a return to nature as a source of novel potential agents [144, 145]. Natural products possess a wide range of bioactivities and were a continuous source of novel drug leads that contributed to approximately $46 \%$ of drugs approved by the Food and Drug Administration from 1981 to 2014 [146-149]. The abovementioned studies have demonstrated that flavonoids are AhR antagonists or agonists. Flavonoids are widely distributed in natural products such as medicinal plants, fruits, vegetables and teas. To date, more than 15,000 flavonoids have been identified from natural products [150]. Due to their importance in the regulation of AhR activity, great effort should be made to further investigate the regulation of flavonoids on AhR activity. A better understanding of their chemical structures and AhR biological activity will be of importance to uncover their further potential as therapeutic drugs and their molecular mechanism.

Third, uremic toxins from tryptophan metabolism and dioxins from environmental pollutants activate the AhR signalling pathway. These toxins induce leukocyte activation and endothelial dysfunction, causing thrombosis and inflammation as well as enhanced vascular oxidative stress. Uremic toxins from tryptophan metabolism that activate AhR explain how these toxins contribute to CVD in CKD patients. These mechanisms of toxicity of uremic toxins may provide new potential therapeutic approaches targeting AhR activation. Although a number of experiments have explored the relationship between AhR activity and various kidney diseases by analysing the target genes of AhR in both animal models and patients with CKD, AhR in kidney disease is still in its infancy compared with cancer and immune disease. A large number of metabolites, especially uremic toxins, have been identified by high-throughput metabolomics, although the number is apparently insufficient. Further studies should be performed on the effect of novel metabolites on AhR activity. In addition, the AhR pathway can interact with the Wnt/ $\beta$-catenin, transforming growth factor- $\beta /$ bone morphogenetic protein and Notch signalling pathways as well as tyrosine kinase receptor pathways, including vascular endothelial growth factor receptor, keratinocyte growth factor receptor and epidermal growth factor receptor, in several human diseases [118]. Many studies have well documented that the transforming growth factor- $\beta /$ bone morphogenetic protein, $\mathrm{Wnt} / \beta$-catenin, Notch signalling and tyrosine kinase receptor pathways are involved in CKD [151, 152]. Few studies have demonstrated whether AhR can interact with these signalling pathways in kidney disease.

Finally, regardless of the promising translational and clinical applications of AhR, most of the knowledge currently available about its physiopathological function has been demonstrated by using animal models, which have led to certain limitations for the direct transfer of achievements into patients. Great effort will surely focus on the 
validation of data from animal experiments to clinical application in the future, and system biology, including genomics, transcriptomics, proteomics, metabolomics and lipidomics, will most likely play an important role in studies on AhR. These are exciting areas for future studies. It is very likely that future studies will provide new diagnostic and prognostic approaches for complex human diseases and may establish new therapeutic strategies targeting AhR activation.

\begin{abstract}
Abbreviations
5/6 Nx: 5/6 nephrectomized; AAl: aristolochic acid I; AAN: aristolochic acid nephropathy; AhR: aryl hydrocarbon receptor; AhR-AP: AhR-activating potential; AhRR: AhR repressor; ARNT: AhR nuclear translocator; CKD: chronic kidney disease; COX-2: cyclooxygenase-2; CVD: cardiovascular disease; CYP1A1: cytochrome P450, family 1, member 1A; CYP1A2: cytochrome P450, family 1 , member 2A; CYP1B1: cytochrome P450, family 1 , sub family B; DIM: diindolylmethane; DRE or XRE: dioxin- or xenobiotic-responsive element; eGFR: estimated glomerular filtration rate; ERK: extracellular signal-regulated kinase; ESRD: end-stage renal disease; HSP90: heat-shock protein 90; HUVECs: human umbilical vein endothelial cells; I3AC: indole-3-acetonitrile; I3C: indole-3-carbinol; IAA: indole-3-acetic acid; ICZ: indolo[3,2,-b]carbazole; IDG: indoxyl- $\beta$-D-glucuronide; IDO: indoleamine 2,3-dioxygenase; IS: indoxyl sulfate; JNK: jun-NH2-terminal kinase; LTr1: [2-indol-3-ylmethyl:-indol-3-yl] indol3-ylmethane; MAPK: mitogen-activated protein kinase; MCP-1: monocyte chemoattractant protein-1; MMP: metalloproteinase; NF-KB: nuclear factor kappa B; Nrf2: nuclear factor-erythroid-2-related factor 2; P23: co-chaperon p23; Per-ARNT-Sim: period-aryl hydrocarbon receptor nuclear translocatorsingle minded; RAS: renin-angiotensin system; RCC: renal cell carcinoma; SLCO4C1: solute carrier organic anion transporter family member 4C1; SULT: sulfotransferase; TCDD: 2,3,7,8-tetrachlorodibenzo-p-dioxin; TDO: tryptophan 2,3-dioxygenase; XAP2: X-associated protein 2.
\end{abstract}

\section{Acknowledgements}

None.

\section{Authors' contributions}

Conceptualization: Y-YZ; Literature search: HZ, LC, YT, Y-LF, BLL, QQL, GY and $Y-Y Z ;$ Writing and formatting: $Y-Y Z$ and NDV; Figures: $Y T$ and $Y-Y Z ;$ Review and editing: NDV, YG and Y-YZ. All authors read and approved the final manuscript.

\section{Funding}

This study was supported by the National Natural Science Foundation of China (Nos. 81673578, 81872985).

\section{Availability of data and materials \\ Not applicable.}

\section{Ethics approval and consent to participate}

Not applicable.

\section{Consent for publication}

Not applicable.

\section{Competing interests}

The authors declare that they have no competing interests.

\section{Author details}

${ }^{1}$ Faculty of Life Science \& Medicine, Northwest University, No. 229 Taibai North Road, Xi'an 710069, Shaanxi, China. ${ }^{2}$ Division of Nephrology and Hypertension, School of Medicine, University of California Irvine, Irvine, CA 92897, USA ${ }^{3}$ Beijing Hospital of Traditional Chinese Medicine, Capital Medical University, Beijing 100010, China. ${ }^{4}$ Department of Internal Medicine, University of New Mexico, Albuquerque 87131, USA.
Received: 8 May 2019 Accepted: 29 August 2019

Published online: 05 September 2019

\section{References}

1. Denison MS, Nagy SR. Activation of the aryl hydrocarbon receptor by structurally diverse exogenous and endogenous chemicals. Annu Rev Pharmacol Toxicol. 2003:43:309-34.

2. Roager HM, Licht TR. Microbial tryptophan catabolites in health and disease. Nat Commun. 2018;9:3294.

3. Tete A, Gallais I, Imran M, Chevanne M, Liamin M, Sparfel L, Bucher S, Burel A, Podechard N, Appenzeller BMR, et al. Mechanisms involved in the death of steatotic WIF-B9 hepatocytes co-exposed to benzo[a] pyrene and ethanol: a possible key role for xenobiotic metabolism and nitric oxide. Free Radic Biol Med. 2018;129:323-37.

4. Denison MS, Vella LM. The hepatic Ah receptor for 2,3,7,8-tetrachlorodibenzo-p-dioxin: species differences in subunit dissociation. Arch Biochem Biophys. 1990;277:382-8.

5. Das DN, Naik PP, Mukhopadhyay S, Panda PK, Sinha N, Meher BR, Bhutia SK. Elimination of dysfunctional mitochondria through mitophagy suppresses benzo[a]pyrene-induced apoptosis. Free Radic Biol Med. 2017;112:452-63.

6. Forman HJ, Finch CE. A critical review of assays for hazardous components of air pollution. Free Radic Biol Med. 2018;117:202-17.

7. Hankinson O. The aryl hydrocarbon receptor complex. Annu Rev Pharmacol Toxicol. 1995;35:307-40.

8. Yamamura K, Uruno T, Shiraishi A, Tanaka Y, Ushijima M, Nakahara T, Watanabe M, Kido-Nakahara M, Tsuge I, Furue M, Fukui Y. The transcription factor EPAS1 links DOCK8 deficiency to atopic skin inflammation via IL-31 induction. Nat Commun. 2017:8:13946.

9. Endo Y, Yokote K, Nakayama T. The obesity-related pathology and Th17 cells. Cell Mol Life Sci. 2017;74:1231-45.

10. Xia P, Liu J, Wang S, Ye B, Du Y, Xiong Z, Han ZG, Tong L, Fan Z. WASH maintains NKp46(+) ILC3 cells by promoting AHR expression. Nat Commun. 2017;8:15685.

11. Kalthoff S, Landerer S, Reich J, Strassburg CP. Protective effects of coffee against oxidative stress induced by the tobacco carcinogen benzo[alpha]pyrene. Free Radic Biol Med. 2017;108:66-76.

12. Sinclair LV, Neyens D, Ramsay G, Taylor PM, Cantrell DA. Single cell analysis of kynurenine and System $L$ amino acid transport in T cells. Nat Commun. 2018;9:1981.

13. Venken $\mathrm{K}$, Jacques P, Mortier C, Labadia ME, Decruy T, Coudenys J, Hoyt K, Wayne AL, Hughes R, Turner M, et al. RORgammat inhibition selectively targets IL-17 producing iNKT and gammadelta-T cells enriched in spondyloarthritis patients. Nat Commun. 2019;10:9.

14. Singh R, Chandrashekharappa S, Bodduluri SR, Baby BV, Hegde B, Kotla NG, Hiwale AA, Saiyed T, Patel P, Vijay-Kumar M, et al. Enhancement of the gut barrier integrity by a microbial metabolite through the Nrf2 pathway. Nat Commun. 2019;10:89.

15. Sampath C, Sprouse JC, Freeman ML, Gangula PR. Activation of Nrf2 attenuates delayed gastric emptying in obesity induced diabetic (T2DM) female mice. Free Radic Biol Med. 2019;135:132-43.

16. Wang GZ, Zhang L, Zhao XC, Gao SH, Qu LW, Yu H, Fang WF, Zhou YC, Liang F, Zhang C, et al. The aryl hydrocarbon receptor mediates tobacco-induced PD-L1 expression and is associated with response to immunotherapy. Nat Commun. 2019;10:1125.

17. Jaeger C, Tischkau SA. Role of aryl hydrocarbon receptor in circadian clock disruption and metabolic dysfunction. Environ Health Insights. 2016;10:133-41.

18. Zhang L, Nichols RG, Correll J, Murray IA, Tanaka N, Smith PB, Hubbard TD, Sebastian A, Albert I, Hatzakis E, et al. Persistent organic pollutants modify gut microbiota-host metabolic homeostasis in mice through aryl hydrocarbon receptor activation. Environ Health Perspect. 2015;123:679-88.

19. Brokken L, Lundberg PJ, Spano M, Manicardi GC, Pedersen HS, Strucinski P, Goralczyk K, Zviezdai V, Jonsson BA, Bonde JP, et al. Interactions between polymorphisms in the aryl hydrocarbon receptor signalling pathway and exposure to persistent organochlorine pollutants affect human semen quality. Reprod Toxicol. 2014;49:65-73. 
20. Kim YC, Seok S, Byun S, Kong B, Zhang Y, Guo G, Xie W, Ma J, Kemper B, Kemper JK. AhR and SHP regulate phosphatidylcholine and S-adenosylmethionine levels in the one-carbon cycle. Nat Commun. 2018;9:540.

21. Phelan D, Winter GM, Rogers WJ, Lam JC, Denison MS. Activation of the Ah receptor signal transduction pathway by bilirubin and biliverdin. Arch Biochem Biophys. 1998;357:155-63.

22. Flaveny CA, Murray IA, Chiaro CR, Perdew GH. Ligand selectivity and gene regulation by the human aryl hydrocarbon receptor in transgenic mice. Mol Pharmacol. 2009:75:1412-20.

23. Nicholson JK, Lindon JC, Holmes E.' 'Metabonomics': understanding the metabolic responses of living systems to pathophysiological stimuli via multivariate statistical analysis of biological NMR spectroscopic data. Xenobiotica. 1999;29:1181-9.

24. Scheubert K, Hufsky F, Petras D, Wang M, Nothias LF, Duhrkop K, Bandeira N, Dorrestein PC, Bocker S. Significance estimation for large scale metabolomics annotations by spectral matching. Nat Commun. 2017:8:1494.

25. Zhao YY, Cheng XL, Vaziri ND, Liu S, Lin RC. UPLC-based metabonomic applications for discovering biomarkers of diseases in clinical chemistry. Clin Biochem. 2014;47:16-26.

26. Zhao YY, Miao H, Cheng XL, Wei F. Lipidomics: novel insight into the biochemical mechanism of lipid metabolism and dysregulation-associated disease. Chem Biol Interact. 2015;240:220-38.

27. Zhao YY, Cheng XL, Lin RC, Wei F. Lipidomics applications for disease biomarker discovery in mammal models. Biomark Med. 2015;9:153-68.

28. Chen DQ, Chen H, Chen L, Tang DD, Miao H, Zhao YY. Metabolomic application in toxicity evaluation and toxicological biomarker identification of natural product. Chem Biol Interact. 2016;252:114-30.

29. Gar C, Rottenkolber M, Prehn C, Adamski J, Seissler J, Lechner A. Serum and plasma amino acids as markers of prediabetes, insulin resistance, and incident diabetes. Crit Rev Clin Lab Sci. 2018:55:21-32.

30. Chen H, Miao H, Feng YL, Zhao YY, Lin RC. Metabolomics in dyslipidemia. Adv Clin Chem. 2014;66:101-19.

31. Zhao YY, Cheng XL, Lin RC. Lipidomics applications for discovering biomarkers of diseases in clinical chemistry. Int Rev Cell Mol Biol. 2014;313:1-26.

32. Zhao YY, Wu SP, Liu S, Zhang Y, Lin RC. Ultra-performance liquid chromatography-mass spectrometry as a sensitive and powerful technology in lipidomic applications. Chem Biol Interact. 2014;220:181-92.

33. Zhao YY, Lin RC. UPLC-MS ${ }^{E}$ application in disease biomarker discovery: the discoveries in proteomics to metabolomics. Chem Biol Interact. 2014:215:7-16.

34. Earl DC, Ferrell PB Jr, Leelatian N, Froese JT, Reisman BJ, Irish JM, Bachmann BO. Discovery of human cell selective effector molecules using single cell multiplexed activity metabolomics. Nat Commun. 2018;9:39.

35. Park KS, Xu CL, Cui X, Tsang SH. Reprogramming the metabolome rescues retinal degeneration. Cell Mol Life Sci. 2018;75:1559-66.

36. Hayton S, Maker GL, Mullaney I, Trengove RD. Experimental design and reporting standards for metabolomics studies of mammalian cell lines. Cell Mol Life Sci. 2017;74:4421-41.

37. Deidda M, Piras C, Cadeddu Dessalvi C, Congia D, Locci E, Ascedu F, De Candia G, Cadeddu M, Lai G, Pirisi R, et al. Blood metabolomic fingerprint is distinct in healthy coronary and in stenosing or microvascular ischemic heart disease. J TransI Med. 2017;15:112.

38. Zhao YY, Cheng XL, Cui JH, Yan XR, Wei F, Bai X, Lin RC. Effect of ergosta4,6,8(14),22-tetraen-3-one (ergone) on adenine-induced chronic renal failure rat: a serum metabonomic study based on ultra performance liquid chromatography/high-sensitivity mass spectrometry coupled with MassLynx i-FIT algorithm. Clin Chim Acta. 2012;413:1438-45.

39. Zhao YY, Li HT, Feng YI, Bai X, Lin RC. Urinary metabonomic study of the surface layer of Poria cocos as an effective treatment for chronic renal injury in rats. J Ethnopharmacol. 2013;148:403-10.

40. Zhao YY, Lei P, Chen DQ, Feng YL, Bai X. Renal metabolic profiling of early renal injury and renoprotective effects of Poria cocos epidermis using UPLC Q-TOF/HSMS/MSE. J Pharm Biomed Anal. 2013;81-82:202-9.

41. Chen DQ, Cao G, Chen H, Argyopoulos CP, Yu H, Su W, Chen L, Samuels DC, Zhuang S, Bayliss GP, et al. Identification of serum metabolites associating with chronic kidney disease progression and anti-fibrotic effect of 5-methoxytryptophan. Nat Commun. 2019;10:1476.

42. Zhao YY. Metabolomics in chronic kidney disease. Clin Chim Acta. 2013:422:59-69.
43. Chen H, Chen L, Liu D, Chen DQ, Vaziri ND, Yu XY, Zhang L, Su W, Bai X, Zhao YY. Combined clinical phenotype and lipidomic analysis reveals the impact of chronic kidney disease on lipid metabolism. J Proteome Res. 2017;16:1566-78.

44. Chen DQ, Chen H, Chen L, Vaziri ND, Wang M, Li XR, Zhao YY. The link between phenotype and fatty acid metabolism in advanced chronic kidney disease. Nephrol Dial Transplant. 2017;32:1154-66.

45. Chen H, Cao G, Chen DQ, Wang M, Vaziri ND, Zhang ZH, Mao JR, Bai X, Zhao YY. Metabolomics insights into activated redox signaling and lipid metabolism dysfunction in chronic kidney disease progression. Redox Biol. 2016;10:168-78.

46. Zhang ZH, Mao JR, Chen H, Su W, Zhang Y, Zhang L, Chen DQ, Zhao $Y Y$, Vaziri ND. Removal of uremic retention products by hemodialysis is coupled with indiscriminate loss of vital metabolites. Clin Biochem. 2017;50:1078-86.

47. Brial F, Le Lay A, Dumas ME, Gauguier D. Implication of gut microbiota metabolites in cardiovascular and metabolic diseases. Cell Mol Life Sci. 2018:75:3977-90.

48. Chen DQ, Cao G, Chen H, Liu D, Su W, Yu XY, Vaziri ND, Liu XH, Bai X, Zhang L, Zhao YY. Gene and protein expressions and metabolomics exhibit activated redox signaling and Wnt/ $\beta$-catenin pathway are associated with metabolite dysfunction in patients with chronic kidney disease. Redox Biol. 2017;12:505-21.

49. Feng YL, Chen H, Chen DQ, Vaziri ND, Su W, Ma SX, Shang YQ, Mao JR, Yu $X Y$, Zhang $L$, et al. Activated NF-KB/Nrf2 and Wnt/ $\beta$-catenin pathways are associated with lipid metabolism in CKD patients with microalbuminuria and macroalbuminuria. Biochim Biophys Acta Mol Basis Dis. 2019;1865:2317-32.

50. Zhao YY, Cheng XL, Wei F, Xiao XY, Sun WJ, Zhang Y, Lin RC. Serum metabonomics study of adenine-induced chronic renal failure in rats by ultra performance liquid chromatography coupled with quadrupole time-of-flight mass spectrometry. Biomarkers. 2012;17:48-55.

51. Vanholder $R$, De Smet $R$, Glorieux $G$, Argiles $A$, Baurmeister U, Brunet $P$, Clark W, Cohen G, De Deyn PP, Deppisch R, et al. Review on uremic toxins: Classification, concentration, and interindividual variability. Kidney Int. 2003;63:1934-43.

52. Duranton F, Cohen G, De Smet R, Rodriguez M, Jankowski J, Vanholder R, Argiles A. Normal and pathologic concentrations of uremic toxins. J Am Soc Nephrol. 2012;23:1258-70.

53. Dolivo DM, Larson SA, Dominko T. Tryptophan metabolites kynurenine and serotonin regulate fibroblast activation and fibrosis. Cell Mol Life Sci. 2018;75:3663-81.

54. Song P, Ramprasath T, Wang H, Zou MH. Abnormal kynurenine pathway of tryptophan catabolism in cardiovascular diseases. Cell Mol Life Sci. 2017;74:2899-916.

55. Fatokun AA, Hunt NH, Ball HJ. Indoleamine 2,3-dioxygenase 2 (IDO2) and the kynurenine pathway: characteristics and potential roles in health and disease. Amino Acids. 2013:45:1319-29.

56. Liu Y, Liang X, Yin X, Lv J, Tang K, Ma J, Ji T, Zhang H, Dong W, Jin X, et al. Blockade of IDO-kynurenine-AhR metabolic circuitry abrogates IFNY-induced immunologic dormancy of tumor-repopulating cells. Nat Commun. 2017;8:15207.

57. Santoro A, Ostan R, Candela M, Biagi E, Brigidi P, Capri M, Franceschi C. Gut microbiota changes in the extreme decades of human life: a focus on centenarians. Cell Mol Life Sci. 2018;75:129-48.

58. Li G, Young KD. Indole production by the tryptophanase TnaA in Escherichia coli is determined by the amount of exogenous tryptophan. Microbiology. 2013;159:402-10.

59. Schroeder JC, Dinatale BC, Murray IA, Flaveny CA, Liu Q, Laurenzana EM, Lin JM, Strom SC, Omiecinski CJ, Amin S, Perdew GH. The uremic toxin 3-indoxyl sulfate is a potent endogenous agonist for the human aryl hydrocarbon receptor. Biochemistry. 2010;49:393-400.

60. Addi T, Dou L, Burtey S. Tryptophan-derived uremic toxins and thrombosis in chronic kidney disease. Toxins. 2018:10:412.

61. Jin UH, Lee SO, Sridharan G, Lee K, Davidson LA, Jayaraman A, Chapkin RS, Alaniz R, Safe S. Microbiome-derived tryptophan metabolites and their aryl hydrocarbon receptor-dependent agonist and antagonist activities. Mol Pharmacol. 2014;85:777-88.

62. Hubbard TD, Murray IA, Bisson WH, Lahoti TS, Gowda K, Amin SG, Patterson AD, Perdew GH. Adaptation of the human aryl hydrocarbon receptor to sense microbiota-derived indoles. Sci Rep. 2015:5:12689. 
63. Weems JM, Yost GS. 3-Methylindole metabolites induce lung CYP1A1 and CYP2F1 enzymes by AhR and non-AhR mechanisms, respectively. Chem Res Toxicol. 2010;23:696-704.

64. Rooks MG, Garrett WS. Gut microbiota, metabolites and host immunity. Nat Rev Immunol. 2016;16:341-52.

65. Li DY, Tang WHW. Contributory role of gut microbiota and their metabolites toward cardiovascular complications in chronic kidney disease. Semin Nephrol. 2018;38:193-205.

66. Vaziri ND, Wong J, Pahl M, Piceno YM, Yuan J, DeSantis TZ, Ni Z, Nguyen $\mathrm{TH}$, Andersen GL. Chronic kidney disease alters intestinal microbial flora. Kidney Int. 2013;83:308-15.

67. Chen YY, Chen DQ, Chen L, Liu JR, Vaziri ND, Guo Y, Zhao YY. Microbiome-metabolome reveals the contribution of gut-kidney axis on kidney disease. J Transl Med. 2019;17:5.

68. Feng YL, Cao G, Chen DQ, Vaziri ND, Chen L, Zhang J, Wang M, Guo Y, Zhao YY. Microbiome-metabolomics reveals gut microbiota associated with glycine-conjugated metabolites and polyamine metabolism in chronic kidney disease. Cell Mol Life Sci. 2019. https://doi.org/10.1007/ s00018-019-03155-9.

69. Chen L, Chen DQ, Liu JR, Zhang J, Vaziri ND, Zhuang S, Chen H, Feng YL, Guo Y, Zhao YY. Unilateral ureteral obstruction causes gut microbial dysbiosis and metabolome disorders contributing to tubulointerstitial fibrosis. Exp Mol Med. 2019;51:38.

70. Iu M, Zago M, Rico de Souza A, Bouttier M, Pareek S, White JH, Hamid Q, Eidelman DH, Baglole CJ. RelB attenuates cigarette smoke extractinduced apoptosis in association with transcriptional regulation of the aryl hydrocarbon receptor. Free Radic Biol Med. 2017;108:19-31.

71. Moura-Alves P, Fae K, Houthuys E, Dorhoi A, Kreuchwig A, Furkert J, Barison N, Diehl A, Munder A, Constant P, et al. AhR sensing of bacterial pigments regulates antibacterial defence. Nature. 2014;512:387-92.

72. Brito JS, Borges NA, Esgalhado M, Magliano DC, Soulage CO, Mafra D. Aryl hydrocarbon receptor activation in chronic kidney disease: role of uremic toxins. Nephron. 2017;137:1-7.

73. Sallee M, Dou L, Cerini C, Poitevin S, Brunet P, Burtey S. The aryl hydrocarbon receptor-activating effect of uremic toxins from tryptophan metabolism: a new concept to understand cardiovascular complications of chronic kidney disease. Toxins. 2014;6:934-49.

74. Gondouin B, Cerini C, Dou L, Sallee M, Duval-Sabatier A, Pletinck A, Calaf R, Lacroix R, Jourde-Chiche N, Poitevin S, et al. Indolic uremic solutes increase tissue factor production in endothelial cells by the aryl hydrocarbon receptor pathway. Kidney Int. 2013;84:733-44.

75. Ichii O, Otsuka-Kanazawa S, Nakamura T, Ueno M, Kon Y, Chen W, Rosenberg AZ, Kopp JB. Podocyte injury caused by indoxyl sulfate, a uremic toxin and aryl-hydrocarbon receptor ligand. PLOS ONE. 2014;9:e108448.

76. Hamano H, Ikeda Y, Watanabe H, Horinouchi Y, Izawa-Ishizawa Y, Imanishi M, Zamami Y, Takechi K, Miyamoto L, Ishizawa K, et al. The uremic toxin indoxyl sulfate interferes with iron metabolism by regulating hepcidin in chronic kidney disease. Nephrol Dial Transplant. 2018:33:586-97.

77. Watanabe I, Tatebe J, Namba S, Koizumi M, Yamazaki J, Morita T. Activation of aryl hydrocarbon receptor mediates indoxyl sulfate-induced monocyte chemoattractant protein-1 expression in human umbilical vein endothelial cells. Circ J. 2013;77:224-30.

78. Dou L, Sallee M, Cerini C, Poitevin S, Gondouin B, Jourde-Chiche N, Fallague $K$, Brunet $P$, Calaf $R$, Dussol B, et al. The cardiovascular effect of the uremic solute indole-3 acetic acid. J Am Soc Nephrol. 2015;26:876-87.

79. Schefold JC, Zeden JP, Fotopoulou C, von Haehling S, Pschowski R, Hasper D, Volk HD, Schuett C, Reinke P. Increased indoleamine 2,3-dioxygenase (IDO) activity and elevated serum levels of tryptophan catabolites in patients with chronic kidney disease: a possible link between chronic inflammation and uraemic symptoms. Nephrol Dial Transplant. 2009;24:1901-8.

80. Kalaska B, Pawlak K, Domaniewski T, Oksztulska-Kolanek E, Znorko B, Roszczenko A, Rogalska J, Brzoska MM, Lipowicz P, Doroszko M, et al. Elevated levels of peripheral kynurenine decrease bone strength in rats with chronic kidney disease. Front Physiol. 2017:8:836.

81. Dou L, Poitevin S, Sallee M, Addi T, Gondouin B, McKay N, Denison MS, Jourde-Chiche N, Duval-Sabatier A, Cerini C, et al. Aryl hydrocarbon receptor is activated in patients and mice with chronic kidney disease. Kidney Int. 2018;93:986-99.
82. Shivanna S, Kolandaivelu K, Shashar M, Belghasim M, Al-Rabadi L, Balcells M, Zhang A, Weinberg J, Francis J, Pollastri MP, et al. The aryl hydrocarbon receptor is a critical regulator of tissue factor stability and an antithrombotic target in uremia. J Am Soc Nephrol. 2016;27:189-201.

83. Kim HY, Yoo TH, Hwang Y, Lee GH, Kim B, Jang J, Yu HT, Kim MC, Cho $J Y$, Lee CJ, et al. Indoxyl sulfate (IS)-mediated immune dysfunction provokes endothelial damage in patients with end-stage renal disease (ESRD). Sci Rep. 2017;7:3057.

84. Harrill JA, Hukkanen RR, Lawson M, Martin G, Gilger B, Soldatow V, Lecluyse EL, Budinsky RA, Rowlands JC, Thomas RS. Knockout of the aryl hydrocarbon receptor results in distinct hepatic and renal phenotypes in rats and mice. Toxicol Appl Pharmacol. 2013;272:503-18.

85. Parrish AR, Alejandro NF, Bowes lii RC, Ramos KS. Cytotoxic response profiles of cultured renal epithelial and mesenchymal cells to selected aromatic hydrocarbons. Toxicol In Vitro. 1998;12:219-32.

86. Baban B, Liu JY, Mozaffari MS. Aryl hydrocarbon receptor agonist, leflunomide, protects the ischemic-reperfused kidney: role of Tregs and stem cells. Am J Physiol Regul Integr Comp Physiol. 2012;303:R1136-46.

87. Taki K, Nakamura S, Miglinas M, Enomoto A, Niwa T. Accumulation of indoxyl sulfate in OAT1/3-positive tubular cells in kidneys of patients with chronic renal failure. J Ren Nutr. 2006;16:199-203.

88. Niwa T, Takeda N, Tatematsu A, Maeda K. Accumulation of indoxyl sulfate, an inhibitor of drug-binding, in uremic serum as demonstrated by internal-surface reversed-phase liquid chromatography. Clin Chem. 1988;34:2264-7.

89. Deguchi T, Nakamura M, Tsutsumi Y, Suenaga A, Otagiri M. Pharmacokinetics and tissue distribution of uraemic indoxyl sulphate in rats. Biopharm Drug Dispos. 2003;24:345-55.

90. Sindhu RK, Vaziri ND. Upregulation of cytochrome P450 1A2 in chronic renal failure: does oxidized tryptophan play a role? Adv Exp Med Biol. 2003:527:401-7.

91. Moriguchi T, Motohashi H, Hosoya T, Nakajima O, Takahashi S, Ohsako S, Aoki Y, Nishimura N, Tohyama C, Fujii-Kuriyama Y, Yamamoto M. Distinct response to dioxin in an arylhydrocarbon receptor (AHR)-humanized mouse. Proc Natl Acad Sci USA. 2003:100:5652-7.

92. Kim JT, Kim SS, Jun DW, Hwang YH, Park WH, Pak YK, Lee HK. Serum arylhydrocarbon receptor transactivating activity is elevated in type 2 diabetic patients with diabetic nephropathy. J Diabetes Investig. 2013;4:483-91.

93. Lee WJ, Liu SH, Chiang CK, Lin SY, Liang KW, Chen CH, Tien HR, Chen PH, Wu JP, Tsai YC, et al. Aryl hydrocarbon receptor deficiency attenuates oxidative stress-related mesangial cell activation and macrophage infiltration and extracellular matrix accumulation in diabetic nephropathy. Antioxid Redox Signal. 2016;24:217-31.

94. Ng HY, Bolati W, Lee CT, Chien YS, Yisireyili M, Saito S, Pei SN, Nishijima F, Niwa T. Indoxyl sulfate downregulates Mas receptor via aryl hydrocarbon receptor/nuclear Factor-kB, and induces cell proliferation and tissue factor expression in vascular smooth muscle cells. Nephron. 2016:133:205-12.

95. Ng HY, Yisireyili M, Saito S, Lee CT, Adelibieke Y, Nishijima F, Niwa T. Indoxyl sulfate downregulates expression of Mas receptor via OAT3/ AhR/Stat3 pathway in proximal tubular cells. PLoS ONE. 2014;9:e91517.

96. Yisireyili M, Saito S, Abudureyimu S, Adelibieke Y, Ng HY, Nishijima F, Takeshita K, Murohara T, Niwa T. Indoxyl sulfate-induced activation of (pro)renin receptor promotes cell proliferation and tissue factor expression in vascular smooth muscle cells. PLOS ONE. 2014;9:e109268.

97. Corre S, Tardif N, Mouchet N, Leclair HM, Boussemart L, Gautron A, Bachelot L, Perrot A, Soshilov A, Rogiers A, et al. Sustained activation of the aryl hydrocarbon receptor transcription factor promotes resistance to BRAF-inhibitors in melanoma. Nat Commun. 2018;9:4775.

98. Ishida M, Mikami S, Shinojima T, Kosaka T, Mizuno R, Kikuchi E, Miyajima A, Okada Y, Oya M. Activation of aryl hydrocarbon receptor promotes invasion of clear cell renal cell carcinoma and is associated with poor prognosis and cigarette smoke. Int J Cancer. 2015;137:299-310.

99. Chen L, Cao G, Wang M, Feng YL, Chen DQ, Vaziri ND, Zhuang S, Zhao YY. The matrix metalloproteinase-13 inhibitor poricoic acid ZI ameliorates renal fibrosis by mitigating epithelial-mesenchymal transition. Mol Nutr Food Res. 2019;63:e1900132.

100. Ishida M, Mikami S, Kikuchi E, Kosaka T, Miyajima A, Nakagawa K, Mukai M, Okada Y, Oya M. Activation of the aryl hydrocarbon receptor pathway enhances cancer cell invasion by upregulating the MMP 
expression and is associated with poor prognosis in upper urinary tract urothelial cancer. Carcinogenesis. 2010;31:287-95.

101. Suzuki T, Toyohara T, Akiyama Y, Takeuchi Y, Mishima E, Suzuki C, Ito S, Soga T, Abe T. Transcriptional regulation of organic anion transporting polypeptide SLCO4C1 as a new therapeutic modality to prevent chronic kidney disease. J Pharm Sci. 2011;100:3696-707.

102. Joo MS, Lee CG, Koo JH, Kim SG. miR-125b transcriptionally increased by Nrf2 inhibits AhR repressor, which protects kidney from cisplatininduced injury. Cell Death Dis. 2013;4:e899.

103. Zhao YY. Traditional uses, phytochemistry, pharmacology, pharmacokinetics and quality control of Polyporus umbellatus (Pers.) Fries: a review. J Ethnopharmacol. 2013;149:35-48.

104. Tian T, Chen H, Zhao YY. Traditional uses, phytochemistry, pharmacology, toxicology and quality control of Alisma orientale (Sam.) Juzep: a review. J Ethnopharmacol. 2014;158:373-87.

105. Chen H, Tian T, Miao H, Zhao YY. Traditional uses, fermentation, phytochemistry and pharmacology of Phellinus linteus: a review. Fitoterapia. 2016;113:6-26.

106. Chen DQ, Feng YL, Chen L, Liu JR, Wang M, Vaziri ND, Zhao YY. Poricoic acid $A$ enhances melatonin inhibition of AKI-to-CKD transition by regulating Gas6/Axl-NF-KB/Nrf2 axis. Free Radic Biol Med. 2019;134:484-97.

107. Wang M, Chen DQ, Chen L, Cao G, Zhao H, Liu D, Vaziri ND, Guo Y, Zhao YY. Novel inhibitors of the cellular renin-angiotensin system components, poricoic acids, target Smad3 phosphorylation and Wnt/B-catenin pathway against renal fibrosis. Br J Pharmacol. 2018;175:2689-708.

108. Gong X, Sucher NJ. Stroke therapy in traditional Chinese medicine (TCM): prospects for drug discovery and development. Trends Pharmacol Sci. 1999;20:191-6.

109. Hao H, Zheng $X$, Wang $G$. Insights into drug discovery from natural medicines using reverse pharmacokinetics. Trends Pharmacol Sci. 2014:35:168-77.

110. Jiang WY. Therapeutic wisdom in traditional Chinese medicine: a perspective from modern science. Trends Pharmacol Sci. 2005;26:558-63.

111. Liu X, Wu WY, Jiang BH, Yang M, Guo DA. Pharmacological tools for the development of traditional Chinese medicine. Trends Pharmacol Sci. 2013;34:620-8

112. Yang T, Chen YY, Liu JR, Zhao H, Vaziri ND, Guo Y, Zhao YY. Natural products against renin-angiotensin system for antifibrosis therapy. Eur J Med Chem. 2019;179:623-33.

113. Feng YL, Chen DQ, Vaziri ND, Guo Y, Zhao YY. Small molecule inhibitors of epithelial-mesenchymal transition for the treatment of cancer and fibrosis. Med Res Rev. 2019. https://doi.org/10.1002/med.21596.

114. Liu D, Chen L, Zhao H, Vaziri ND, Ma SC, Zhao YY. Small molecules from natural products targeting the $\mathrm{Wnt} / \beta$-catenin pathway as a therapeutic strategy. Biomed Pharmacother. 2019;117:108990.

115. Chen YY, Yu XY, Chen L, Vaziri ND, Ma SC, Zhao YY. Redox signaling in aging kidney and opportunity for therapeutic intervention through natural products. Free Radic Biol Med. 2019;141:141-9.

116. Xue Z, Li D, Yu W, Zhang Q, Hou X, He Y, Kou X. Mechanisms and therapeutic prospects of polyphenols as modulators of the aryl hydrocarbon receptor. Food Funct. 2017:8:1414-37.

117. Shinde R, McGaha TL. The aryl hydrocarbon receptor: connecting immunity to the microenvironment. Trends Immunol. 2018:39:1005-20

118. Roman AC, Carvajal-Gonzalez JM, Merino JM, Mulero-Navarro S, Fernandez-Salguero PM. The aryl hydrocarbon receptor in the crossroad of signalling networks with therapeutic value. Pharmacol Ther. 2018:185:50-63.

119. Kalthoff S, Strassburg CP. Contribution of human UDP-glucuronosyltransferases to the antioxidant effects of propolis, artichoke and silymarin. Phytomedicine. 2019;56:35-9.

120. Wattenberg LW, Loub WD. Inhibition of polycyclic aromatic hydrocarbon-induced neoplasia by naturally occurring indoles. Cancer Res. 1978;38:1410-3.

121. Bjeldanes LF, Kim JY, Grose KR, Bartholomew JC, Bradfield CA. Aromatic hydrocarbon responsiveness-receptor agonists generated from indole3-carbinol in vitro and in vivo: comparisons with 2,3,7,8-tetrachlorodibenzo-p-dioxin. Proc Natl Acad Sci USA. 1991;88:9543-7.

122. Lamas B, Natividad JM, Sokol H. Aryl hydrocarbon receptor and intestinal immunity. Mucosal Immunol. 2018;11:1024-38.

123. Popolo A, Pinto A, Daglia M, Nabavi SF, Faroogi AA, Rastrelli L. Two likely targets for the anti-cancer effect of indole derivatives from cruciferous vegetables: PI3K/Akt/mTOR signalling pathway and the aryl hydrocarbon receptor. Semin Cancer Biol. 2017;46:132-7.

124. Esser C, Rannug A. The aryl hydrocarbon receptor in barrier organ physiology, immunology, and toxicology. Pharmacol Rev. 2015;67:259-79.

125. Sonderby IE, Geu-Flores F, Halkier BA. Biosynthesis of glucosinolatesgene discovery and beyond. Trends Plant Sci. 2010;15:283-90.

126. Mohammadi-Bardbori A, Bengtsson J, Rannug U, Rannug A, Wincent E. Quercetin, resveratrol, and curcumin are indirect activators of the aryl hydrocarbon receptor (AHR). Chem Res Toxicol. 2012;25:1878-84.

127. Perez-Jimenez J, Neveu V, Vos F, Scalbert A. Systematic analysis of the content of 502 polyphenols in 452 foods and beverages: an application of the phenol-explorer database. J Agric Food Chem. 2010;58:4959-69.

128. Chen L, Teng H, Xie Z, Cao H, Cheang WS, Skalicka-Woniak K, Georgiev Ml, Xiao J. Modifications of dietary flavonoids towards improved bioactivity: an update on structure-activity relationship. Crit Rev Food Sci Nutr. 2018;58:513-27.

129. Jin UH, Park H, Li X, Davidson LA, Allred C, Patil B, Jayaprakasha G, Orr AA, Mao L, Chapkin RS, et al. Structure-dependent modulation of aryl hydrocarbon receptor-mediated activities by flavonoids. Toxicol Sci. 2018;164:205-17.

130. Yang T, Feng YL, Chen L, Vaziri ND, Zhao YY. Dietary natural flavonoids treating cancer by targeting aryl hydrocarbon receptor. Crit Rev Toxicol. 2019. https://doi.org/10.1080/10408444.2019.1635987.

131. Androutsopoulos VP, Papakyriakou A, Vourloumis D, Tsatsakis AM, Spandidos DA. Dietary flavonoids in cancer therapy and prevention: substrates and inhibitors of cytochrome P450 CYP1 enzymes. Pharmacol Ther. 2010;126:9-20.

132. Chen AY, Chen YC. A review of the dietary flavonoid, kaempferol on human health and cancer chemoprevention. Food Chem. 2013;138:2099-107.

133. Zhao YY, Wang HL, Cheng XL, Wei F, Bai X, Lin RC, Vaziri ND. Metabolomics analysis reveals the association between lipid abnormalities and oxidative stress, inflammation, fibrosis, and Nrf2 dysfunction in aristolochic acid-induced nephropathy. Sci Rep. 2015:5:12936.

134. Debelle FD, Vanherweghem JL, Nortier JL. Aristolochic acid nephropathy: a worldwide problem. Kidney Int. 2008;74:158-69.

135. Michl J, Ingrouille MJ, Simmonds MS, Heinrich M. Naturally occurring aristolochic acid analogues and their toxicities. Nat Prod Rep. 2014;31:676-93.

136. Chan CK, Liu Y, Pavlovic NM, Chan W. Etiology of balkan endemic nephropathy: an update on aristolochic acids exposure mechanisms. Chem Res Toxicol. 2018:31:1109-10

137. Wang K, Feng C, Li C, Yao J, Xie X, Gong L, Luan Y, Xing G, Zhu X, Qi X, Ren J. Baicalin protects mice from aristolochic acid l-induced kidney injury by induction of CYP1A through the aromatic hydrocarbon receptor. Int J Mol Sci. 2015;16:16454-68.

138. Feng C, Xie X, Wu M, Li C, Gao M, Liu M, Qi X, Ren J. Tanshinone I protects mice from aristolochic acid l-induced kidney injury by induction of CYP1A. Environ Toxicol Pharmacol. 2013;36:850-7.

139. Zhao YY, Lin RC. Metabolomics in nephrotoxicity. Adv Clin Chem. 2014:65:69-89.

140. Zhao YY, Vaziri ND, Lin RC. Lipidomics: new insight into kidney disease. Adv Clin Chem. 2015;68:153-75.

141. Hocher B, Adamski J. Metabolomics for clinical use and research in chronic kidney disease. Nat Rev Nephrol. 2017;13:269-84.

142. Zhao YY, Liu J, Cheng XL, Bai X, Lin RC. Urinary metabonomics study on biochemical changes in an experimental model of chronic renal failure by adenine based on UPLC Q-TOF/MS. Clin Chim Acta. 2012;413:642-9.

143. Zhang ZH, Chen H, Vaziri ND, Mao JR, Zhang L, Bai X, Zhao YY. Metabolomic signatures of chronic kidney disease of diverse etiologies in the rats and humans. J Proteome Res. 2016;15:3802-12.

144. Chen DQ, Feng YL, Cao G, Zhao YY. Natural products as a source for antifibrosis therapy. Trends Pharmacol Sci. 2018;39:937-52.

145. Moloney MG. Natural products as a source for novel antibiotics. Trends Pharmacol Sci. 2016;37:689-701.

146. Newman DJ, Cragg GM. Natural products as sources of new drugs from 1981 to 2014. J Nat Prod. 2016;79:629-61.

147. Rodrigues T, Reker D, Schneider P, Schneider G. Counting on natural products for drug design. Nat Chem. 2016;8:531-41. 
148. Harvey AL, Edrada-Ebel R, Quinn RJ. The re-emergence of natural products for drug discovery in the genomics era. Nat Rev Drug Discov. 2015;14:111-29.

149. Butler MS, Robertson AA, Cooper MA. Natural product and natural product derived drugs in clinical trials. Nat Prod Rep. 2014;31:1612-61.

150. Xiao J. Dietary flavonoid aglycones and their glycosides: which show better biological significance? Crit Rev Food Sci Nutr. 2017;57:1874-905.

151. Edeling M, Ragi G, Huang S, Pavenstadt H, Susztak K. Developmental signalling pathways in renal fibrosis: the roles of Notch, Wnt and Hedgehog. Nat Rev Nephrol. 2016;12:426-39.
152. Chen L, Yang T, Lu DW, Zhao H, Feng YL, Chen H, Chen DQ, Vaziri ND, Zhao YY. Central role of dysregulation of TGF- $\beta /$ Smad in CKD progression and potential targets of its treatment. Biomed Pharmacother. 2018;101:670-81.

\section{Publisher's Note}

Springer Nature remains neutral with regard to jurisdictional claims in published maps and institutional affiliations.
Ready to submit your research? Choose BMC and benefit from:

- fast, convenient online submission

- thorough peer review by experienced researchers in your field

- rapid publication on acceptance

- support for research data, including large and complex data types

- gold Open Access which fosters wider collaboration and increased citations

- maximum visibility for your research: over 100M website views per year

At BMC, research is always in progress.

Learn more biomedcentral.com/submissions 